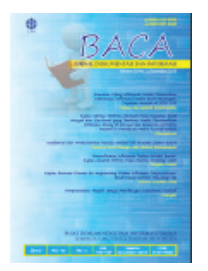

\title{
HUBUNGAN PERILAKU PENCARIAN INFORMASI PEREMPUAN DENGAN KEBUTUHAN FASHION
}

\author{
Cindy Amanda*, Prijana, Andri Yanto \\ Program Studi Ilmu Perpustakaan Fakultas Ilmu Komunikasi - Universitas Padjadjaran \\ *Korespondensi: cindyamanda27@gmail.com
}

Diajukan: 17 Juni 2017; Direview: 26 Juli 2017; Diterima: 25 Agustus 2017; Direvisi: 25 September 2017

\begin{abstract}
This article analyzes about women's information seeking behavior with fashion needs. The aim of the research is to recognize the information seeking behavior of woman for fashion needs, at the Faculty of Communication Sciences of Padjajaran University. The paradigm of this study is post-positivism with a quantitative approach. The method used is correlational with Pearson's product-moment correlation statistic test. The population of this study are 92 people with accidental sampling technique. The result of this study concludes that the information seeking behavior of women is moderately related with fashion needs. The constantly developing fashion needs requires woman to search for information which will later form an information seeking behavior based on the intensity of media use.
\end{abstract}

\begin{abstract}
ABSTRAK
Artikel ini menganalisis mengenai hubungan perilaku pencarian informasi perempuan dengan kebutuhan fashion. Tujuan penelitian ini adalah mengetahui perilaku pencarian informasi perempuan dengan kebutuhan fashion di Fakultas Ilmu Komunikasi Universitas Padjadjaran. Paradigma penelitian ini adalah post-positivism dengan pendekatan kuantitatif. Metode yang digunakan adalah korelasional dengan uji statistik pearson product moment. Populasi penelitian ini adalah mahasiswa tingkat sarjana Fakultas Ilmu Komunikasi Unpad dengan jumlah sampling sebanyak 92 orang dengan teknik sampling accidental. Hasil penelitian ini menyimpulkan bahwa perilaku pencarian informasi perempuan berhubungan moderat dengan kebutuhan fashion. Kebutuhan fashion yang berkembang menuntut perempuan mencari informasi yang kemudian membentuk pola perilaku pencarian informasi berdasarkan intensitas penggunaan media.
\end{abstract}

Keywords: Information seeking; Information searching behavior; Fashion needs; Women

\section{PENDAHULUAN}

Perkembangan teknologi informasi yang begitu pesat pada saat ini memberikan kemudahan pada manusia untuk memenuhi berbagai kebutuhan hidupnya. Di samping kebutuhan sandang, pangan, dan papan, salah satu kebutuhan manusia adalah kebutuhan akan informasi. Kebutuhan akan informasi muncul pada saat seseorang menyadari bahwa kurangnya pengetahuan dan pemahamanannya terhadap sesuatu yang bertujuan untuk mencapai tujuan, menjawab pertanyaan, dan sebagainya (Batley, 2007).

Menurut Belkin (1989) dalam Nicholas (2000) kebutuhan informasi meningkat ketika seseorang menyadari adanya kesenjangan antara pengetahuan dan hasil untuk memecahkan masalah. Upaya untuk mengatasi kesenjangan tersebut seseorang akan memanfaatkan perkembangan teknologi dalam mengakses media informasi. Lebih lanjut Rachmawati dan Winoto (2015) menyatakan bahwa yang mempengaruhi pencarian informasi adalah pandangan seseorang tentang risiko dan imbalan yang akan dihadapi jika ia benar-benar melakukan pencarian informasi. Seseorang sangat mempertimbangkan berbagai manfaat yang akan diperoleh dalam proses pencarian informasi serta pemilihan media yang sesuai dengan 
kebutuhannya. Individu akan melakukan interaksi dengan media tekstual seperti buku, majalah, jurnal ilmiah, koran atau perpustakaan dan juga melalui media yang berbasis komputer seperti internet (Sari, Yusup dan Erwina, 2013).

Salah satu media informasi yang dapat memenuhi kebutuhan informasi tersebut adalah internet. Pemanfaatan internet merubah pola perilaku masyarakat dalam menentukan informasi yang akan diakses. Melalui internet setiap orang dapat mencari berbagai sumber informasi dengan jumlah yang sangat banyak dan up-to-date. Akan tetapi, setiap individu tidak selalu memakai cara yang sama dan umum dalam pencarian informasi. Pencarian informasi merupakan bagian dari perilaku informasi. Perilaku pencarian informasi dilakukan oleh semua orang untuk memenuhi pengetahuan yang diinginkan. Tidak terkecuali oleh perempuan. Perempuan membutuhkan berbagai jenis informasi salah satunya adalah informasi gaya hidup (lifestyle). Informasi gaya hidup yang paling banyak diakses oleh perempuan adalah informasi mengenai fashion.

Menurut Plummer (1983) dalam Kaparang (2013) menjelaskan bahwa gaya hidup adalah cara individu yang diidentifikasikan oleh bagaimana orang menghabiskan waktu mereka (aktivitas), apa yang dianggap penting dalam hidupnya (ketertarikan) dan apa yang mereka pikirkan tentang dunia sekitarnya. Informasi gaya hidup mencakup banyak hal seperti, informasi seputar fashion, kesehatan, travelling, makanan, musik dan seputar kehidupan tokoh dunia/ selebriti.

Perempuan dan fashion tidak dapat dipisahkan, seperti yang dijelaskan dalam penelitian yang berjudul Fashion sebagai Pencitraan Diri dan Identitas Budaya oleh Rahmadya Putra Nugraha pada tahun 2012, bahwa fashion adalah bagian dari gaya keseharian yang berguna sebagai sebuah alat komunikasi untuk menunjukan identitas dirinya. Fashion dapat menjadi etalase kecil tentang diri seseorang bagi orang lain. Gaya berpakaian merupakan penilaian awal seseorang dan fashion menjadi cara untuk mengekpresikan diri seseorang (Hendraningrum dan Susilo, 2008: 25). Sedangkan menurut Hume dan Mills (2013) dalam Dewi, Kebayanti dan Ranteallo (2015) pakaian menjadi simbol penting dalam masyarakat, dengan pakaian seseorang dapat merefleksikan persepsi tentang diri mereka dan orang lain.

Banyaknya informasi fashion yang dimiliki seorang perempuan, memberikan kemudahan baginya untuk dapat berpakaian sesuai dengan kepribadiannya tetapi tetap mengikuti perkembangan fashion sehingga memberikan kepercayaan diri yang besar untuk tampil di depan khayalak umum. Begitu pesatnya perkembangan fashion membuat perempuan harus terus mencari informasi agar kebutuhan informasi fashion terpenuhi dan tidak menimbulkan kesenjangan. Menurut Wersig, manusia membutuhkan informasi karena adanya problematic situation (Indah, 2014). Situasi problematik adalah situasi yang muncul ketika seseorang merasa adanya kesenjangan informasi pada dirinya. Situasi problematik disini adalah situasi dimana perempuan merasakan kurangnya informasi/ pengetahuan yang mereka miliki terhadap kebutuhan fashion. Salah satu upaya yang dilakukan untuk mengatasi situasi problematik dengan melakukan pencarian informasi menggunakan internet. Berdasarkan pada latar belakang di atas, peneliti tertarik untuk melakukan penelitian tentang perilaku pencarian informasi perempuan terhadap pemenuhan kebutuhan fashion dilihat dari motif, faktor dan penggunaan media dalam mencari informasi. 
Permasalahan penelitian ini adalah: apakah motif individu berhubungan secara signifikan dengan kebutuhan fashion?; apakah faktor lingkungan berhubungan secara signifikan dengan kebutuhan fashion?; dan apakah perilaku penggunaan media internet berhubungan secara signifikan dengan kebutuhan fashion?. Tujuan dari penelitian ini untuk: mengetahui hubungan antara motif individu dengan kebutuhan fashion, mengetahui hubungan faktor lingkungan dengan kebutuhan fashion, dan mengetahui hubungan perilaku penggunaan media internet dengan kebutuhan fashion. Hasil penelitian ini diharapkan dapat dijadikan referensi dan rujukan untuk penelitian terkait perilaku pencarian informasi perempuan dan kebutuhan fashion.

\section{TINJAUAN PUSTAKA}

\subsection{Perilaku Pencarian Informasi}

Wilson (2000) mengartikan perilaku sebagai:

1) tingkah laku yang timbul dari diri seseorang;

2) segala sesuatu yang dilakukan oleh seseorang meliputi tindakan dan respons terhadap stimulan;

3) respon seseorang dari lingkungannya.

Perilaku informasi dapat dijabarkan dalam empat istilah berikut: perilaku informasi itu sendiri, perilaku penemuan informasi, perilaku pencarian informasi, dan perilaku penggunaan informasi. Berikut ini adalah pengertian dari keempat istilah dalam perilaku informasi di atas, sebagaimana diterjemahkan oleh Pendit (2003) dari Wilson.

1) Perilaku informasi (information behavior) merupakan keseluruhan perilaku manusia berkaitan dengan sumber dan saluran informasi, termasuk perilaku pencarian dan penggunaan informasi baik secara aktif maupun pasif.

2) Perilaku penemuan informasi (information seeking behavior) merupakan upaya menemukan informasi dengan tujuan tertentu. Dalam upaya ini, seseorang bisa berinteraksi dengan sistem informasi hastawi atau berbasis komputer.

3) Perilaku pencarian informasi (information searching behavior), berupa perilaku mencari pada saat berinteraksi dengan sistem informasi. Perilaku ini terdiri atas berbagai bentuk interaksi dengan sistem, baik di tingkat interaksi dengan komputer, maupun di tingkat intelektual dan mental.

4) Perilaku penggunaan informasi (information use behavior), terdiri atas tindakan tindakan fisik maupun mental yang dilakukan seseorang ketika menggabungkan informasi yang ditemukannya dengan pengetahuan dasar yang sudah dimiliki.

Menurut Rozinah (2012) perilaku pencarian informasi merupakan tindakan yang dilakukan seseorang untuk memenuhi kebutuhannya. Wilson (2000) menjelaskan perilaku pencarian informasi adalah perilaku mikro, yang ditunjukkan seseorang ketika berinteraksi dengan sistem informasi. Perilaku pencarian informasi bertujuan untuk mencari informasi yang sesuai dengan yang dibutuhkan. Perilaku pencarian informasi timbul karena kebutuhan seseorang untuk menjaga status dengan memiliki lebih banyak pengetahuan tentang suatu topik.

Lebih lanjut Gumilar, Winoto dan Anwar (2016) menyatakan bahwa kebutuhan informasi merupakan suatu keadaan yang terjadi dalam struktur kognisi seseorang yang dirasakan ada kekosongan informasi atau pengetahuan sebagai akibat tugas atau sekedar ingin tahu. Seseorang dalam memenuhi kebutuhan informasinya disebabkan oleh adanya ketiadaan informasi dengan berbagai motif pencarian. Selanjutnya Krikelas (1983) menjelaskan bahwa, kebutuhan informasi adalah pengakuan tentang adanya ketidakpastian dalam 
diri seseorang yang mendorong seorang untuk mencari informasi. Kebutuhan informasi sama dengan keinginan tehadap informasi yang dipengaruhi oleh berbagai faktor, baik faktor internal maupun faktor eksternal.

Berdasarkan uraian di atas dapat ditarik kesimpulan bahwa perilaku pencarian informasi adalah suatu aktivitas yang dilakukan oleh seseorang dalam mencari informasi sesuai dengan kebutuhannya guna untuk menambah wawasan dalam mencapai tujuan tertentu.

\subsection{Fashion}

Troxell dan Stone (1981) mendefinisikan fashion sebagai gaya yang diterima dan digunakan oleh mayoritas anggota sebuah kelompok dalam satu waktu tertentu. Semua orang memiliki selera fashion yang berbeda didasarkan pada tujuan pembelian produk fashion. Pembelian produk fashion tidak hanya mengenai atribut saja melainkan juga nilai dari produk tersebut. Contohnya pada saat membeli pakaian, pembelian ini dikarenakan pakaian memiliki arti simbolik, image dan kepuasaan psikologis. Menurut Solomon (2004) dalam Margaretha dan Lisan (2011) pakaian merupakan bagian dari produk fashion yang dikenal dapat mencerminkan kehidupan sosial konsumen, fantasi dan keanggotaanya. Menurut Kaiser (1990) pakaian dapat memperlihatkan status sosial pemakaianya, image, dan karakteristik pribadi mereka. Cara berpakaian yang mengikuti fashion memperlihatkan kepribadian dan idealisme seseorang.

Menurut Nugraha (2012) fashion dan perempuan adalah hal yang tidak dapat dipisahkan. Menurut Trisnawati, dunia fashion sangat identik dengan perempuan sebagaimana yang dikatakan Wilson "fashion is righty or wrongly, primarity associated with women". Oleh karena itu pakaian untuk perempuan cenderung memiliki model dan jenis yang bervariasi. Lebih lanjut Trisnawati menjelaskan perempuan pada usia 17 - 25 tahun cenderung lebih terpengaruh oleh perkembangan fashion karena memiliki keinginan selalu menonjolkan diri di lingkungannya dengan cara memperhatikan penampilan fisiknya di atas segalanya. Apa yang mereka pakai menentukan keberhasilan mereka dalam hubungan pertemanan dan lingkungan. Dengan pakaian yang mereka kenakan, mereka melekatkan nilai - nilai, kesan, dan pesan dari apa yang dikenakan. Hal ini sesuai dengan konsep dari Willis, "young people learn about their inner selves partly by developing their outer image through clothes. They use style in the symbolic work to express and develop their inderstanding of themselves as unique person, to signifying who they are and they think they are". (Trisnawati, 2011).

Fashion banyak difungsikan sebagai nilai oleh para perempuan karena sistem nilai masyarakat yang menuntut perempuan untuk sadar akan kualitas fisiknya. Seorang perempuan sebagai pribadi yang feminin, berusaha untuk selalu menunjukkan indentitas dan jati dirinya dengan menggunakan produk fashion sebagai image dan citra diri mereka. Penghargaan terhadap diri sendiri adalah bagian penting bagi perempuan karena perempuan memperoleh rasa percaya diri ketika menunjukkan eksistensinya di masyarakat. Fashion merupakan objek untuk mendapatkan nilai percaya diri dengan tampil fashionable untuk membuktikan eksistensi dirinya. Oleh sebab itu, perempuan sangat membutuhkan berbagai jenis informasi terkait lifestyle, tidak terkecuali fashion.

\section{METODE}

Penelitian ini menggunakan pendekatan kuantitatif, penelitian kuantitatif disini adalah kuantitatif post-positivism yang lebih menonjolkan verifikasi data. Penelitian kuantitatif dipengaruhi oleh berpikir kausalitatif yaitu sebab - akibat dan bersifat $a$ 
priori (Prijana, Winoto, dan Yanto, 2016). Adapun metode penelitian bersifat korelasional, dimana metode korelasioal ini berkaitan dengan pengumpulan data untuk menentukan ada atau tidaknya hubungan antara dua variabel/ lebih dan seberapa kuat tingkat hubungan (tingkat hubungan dinyatakan sebagai koefisien korelasi). Analisis data menggunakan uji korelasi pearson product moment. Populasi penelitian ini adalah mahasiswi Fakultas Ilmu Komunikasi Universitas Padjadjaran angkatan 2014-2016 yang berjumlah 1.072 orang. Teknik sampling yang digunakan adalah accidental sampling dengan jumlah sampel sebanyak 92 orang yang dihitung menggunakan rumus Slovin. Pengumpulan data dilakukan melalui kuesioner dan studi pustaka.

\section{HASIL DAN PEMBAHASAN}

\subsection{Uji Hipotesis X1 dan Y}

Untuk mengetahui apakah terdapat hubungan antara motif individu dengan kebutuhan fashion, maka dilakukan analisis statistik dengan menggunakan pearson product moment dengan hipotesis sebagai berikut:

$\mathrm{H}_{0} \quad$ : Motif individu berhubungan non signifikan dengan kebutuhan fashion

$\mathrm{H}_{1} \quad$ : Motif individu berhubungan signifikan dengan kebutuhan fashion

Berdasarkan hasil pengujian menggunakan uji korelasi pearson product moment di peroleh 0,337. Perhitungan uji korelasi dilakukan menggunakan aplikasi statistik SPSS versi 22 dengan hasil sebagai berikut:

Tabel 1 Korelasi Antara Motif Individu dengan Kebutuhan Fashion

\section{Correlations}

\begin{tabular}{|l|l|l|r|r|}
\hline \multicolumn{2}{|c|}{} & $\mathrm{X} 1$ & \multicolumn{1}{|c|}{$\mathrm{Y}$} \\
\hline X1 & Motif Individu & Pearson Correlation & 1 & $.337^{* *}$ \\
\cline { 3 - 5 } & & Sig. (2-tailed) & & .001 \\
\cline { 3 - 5 } & $\mathrm{N}$ & 92 & 92 \\
\hline Y & \multirow{2}{*}{ Kebutuhan Fashion } & Pearson Correlation & $.337^{* *}$ & 1 \\
\cline { 3 - 5 } & & Sig. (2-tailed) & .001 & 92 \\
\cline { 3 - 5 } & $\mathrm{N}$ & 92 & 92 \\
\hline
\end{tabular}

Motif individu dalam pencarian informasi fashion dipengaruhi oleh kebutuhan fisiologis, kebutuhan kognitif dan kebutuhan afektif seseorang. Setiap orang memiliki kebutuhan informasi yang berbeda - beda. Kebutuhan akan informasi muncul pada saat seseorang menyadari bahwa kurangnya pengetahuan dan pemahamanannya terhadap sesuatu yang bertujuan untuk mencapai tujuan, menjawab pertanyaan, dan sebagainya (Batley, 2007: 19). Menurut Belkin (1989) dalam Nicholas (2000) kebutuhan informasi meningkat ketika seseorang menyadari adanya kesenjangan antara pengetahuan dan hasil untuk memecahkan masalah. Untuk mengatasi kesenjangan yang ada, maka seseorang akan mencari informasi yang sesuai dengan kebutuhan yang diinginkan.

Dalam penelitian ini, kebutuhan fisiologis dari responden diukur dari seberapa banyak responden yang menyatakan bahwa fashion adalah kebutuhan primer mereka. Untuk kebutuhan kognitif diukur dari seberapa banyak responden yang menyatakan bahwa tujuan mencari informasi fashion untuk menambah informasi mengenai perkembangan fashion. Untuk kebutuhan afektif diukur dari seberapa banyak responden yang menyatakan bahwa 
mencari informasi fashion memberikan kesenangan tersendiri dari mereka. Hal ini dikuatkan oleh pernyataan Widyastuti, Rachmawati dan Kurniasih (2014) bahwa dinamika perubahan remaja dalam cara-cara fashion yang berbeda begitu jelas mencerminkan proses pembentukan gaya hidup yang lebih luas. Fashion menegaskan identitas sosial seseorang dan secara bersamaan membiarkan individu membedakan dirinya dari yang lain. Sehingga motivasi mereka dalam mencari informasi sangat erat hubungannya dengan kebutuhan informasi fashion untuk membentuk identitas sosial dan sebagai pembeda dari yang lainnya.

Berdasarkan hasil analisis data dapat disimpulkan bahwa sub variabel $\mathrm{X} 1$ yaitu motif individu dalam pencarian informasi fashion berhubungan signifikan dengan variabel $\mathrm{Y}$ yaitu kebutuhan informasi akan fashion. Hal ini mengindikasikan bahwa fashion adalah kebutuhan primer yang menuntut seseorang untuk mencari informasi agar menambah informasi mengenai perkembangan fashion dan menimbulkan kesenangan sendiri pada saat mencari informasi tersebut. Kebutuhan fisiologis, kognitif dan afektif dalam memperoleh informasi mengenai fashion berhubungan dengan kebutuhan akan informasi fashion.

\subsection{Uji Hipotesis X2 dan Y}

Untuk mengetahui apakah terdapat hubungan antara faktor lingkungan dengan kebutuhan fashion, maka dilakukan analisis statistik dengan menggunakan pearson product moment dengan hipotesis sebagai berikut:

$\mathrm{H}_{0} \quad$ : Faktor lingkungan berhubungan non signifikan dengan kebutuhan fashion

$\mathrm{H}_{1} \quad$ : Faktor lingkungan berhubungan signifikan dengan kebutuhan fashion

Berdasarkan hasil pengujian menggunakan uji korelasi pearson product moment di peroleh 0,239. Perhitungan uji korelasi dilakukan menggunakan aplikasi statistik SPSS versi 22 dengan hasil sebagai berikut:

Tabel 2 Korelasi Antara Faktor Lingkungan dengan Kebutuhan Fashion

Correlations

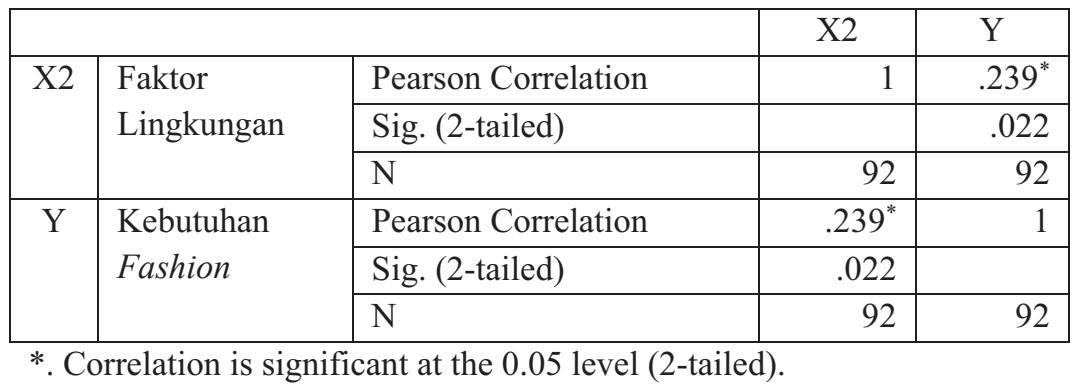

Faktor lingkungan mempengaruhi pencarian informasi fashion. Faktor lingkungan yang mempengaruhi adalah keluarga, teman dan media. Perilaku pencarian setiap orang dipengaruhi oleh faktor yang berbeda - beda. Menurut Heiström (2013) perbedaan dalam pencarian informasi berkaitan dengan karakter keterbukaan pada pengalaman, keberbukaan terhadap kesepakatan dan sikap berhati - hati. Setiap individu tidak selalu memakai cara yang sama dan umum dalam pencarian informasi.

Keteraturan pola pencarian informasi salah satunya adalah perbedaan kepribadian. Wilson (1999) menyatakan bahwa aspek sosial budaya, ekonomi, politik, serta peran sosial 
manusia sebagai aspek yang mempengaruhi perilaku perbedaan pencarian informasi antara individu dengan individu, ataupun antara satu kelompok dengan kelompok lainnya. Pencarian informasi merupakan suatu hal yang dilakukan setiap harinya oleh semua orang baik itu berguna untuk penelitian maupun untuk kebutuhan - kebutuhan lainnya.

Dalam penelitian ini, faktor keluarga yang mempengaruhi pencarian informasi fashion diukur dari seberapa banyak responden yang menyatakan bahwa keluarga mendukung untuk tampil fashionable. Untuk faktor teman yang mempengaruhi pencarian informasi fashion diukur dari seberapa banyak responden menyatakan bahwa lingkungan pertemanan menuntut untuk mencari informasi fashion. Untuk faktor media yang mempengaruhi pencarian informasi fashion diukur dari seberapa banyak responden menyatakan bahwa informasi fashion bisa dicari dan didapatkan dari berbagai media.

Berdasarkan hasil uraian di atas dapat disimpulkan bahwa sub variabel X2 yaitu faktor lingkungan mempengaruhi pencarian informasi fashion berhubungan signifikan dengan variabel Y yaitu kebutuhan fashion. Hal ini mengindikasikan kebutuhan fashion seseorang dipengaruhi oleh faktor lingkungan yang menuntut seseorang untuk mencari informasi mengenai fashion. Faktor keluarga, teman dan media dalam pencarian informasi fashion berhubungan dengan kebutuhan akan informasi fashion.

\subsection{Uji Hipotesis X3 dan Y}

Untuk mengetahui apakah terdapat hubungan antara perilaku penggunaan media internet dengan kebutuhan fashion, maka dilakukan analisis statistik dengan menggunakan pearson product moment dengan hipotesis sebagai berikut:

$\mathrm{H}_{0} \quad$ : Perilaku penggunaan media internet berhubungan non signifikan dengan kebutuhan fashion

$\mathrm{H}_{1} \quad$ : Perilaku penggunaan media internet berhubungan signifikan dengan kebutuhan fashion

Berdasarkan hasil pengujian menggunakan uji korelasi pearson product moment di peroleh 0,353 . Perhitungan uji korelasi dilakukan menggunakan aplikasi statistik SPSS versi 22 dengan hasil sebagai berikut:

Tabel 3 Korelasi Antara Perilaku Informasi dengan Kebutuhan Fashion

\begin{tabular}{|c|c|c|c|c|}
\hline \multicolumn{5}{|c|}{ Correlations } \\
\hline & & & $\mathrm{X} 3$ & Y1 \\
\hline \multirow[t]{3}{*}{$\mathrm{X} 3$} & \multirow{3}{*}{$\begin{array}{l}\text { Perilaku } \\
\text { Informasi }\end{array}$} & Pearson Correlation & 1 & $.353^{* *}$ \\
\hline & & Sig. (2-tailed) & & .001 \\
\hline & & $\mathrm{N}$ & 92 & 92 \\
\hline \multirow[t]{3}{*}{$\mathrm{Y}$} & \multirow{3}{*}{$\begin{array}{l}\text { Kebutuhan } \\
\text { Fashion }\end{array}$} & Pearson Correlation & $.353^{* *}$ & 1 \\
\hline & & Sig. (2-tailed) & .001 & \\
\hline & & $\mathrm{N}$ & 92 & 92 \\
\hline
\end{tabular}

Perilaku penggunaan media dalam pencarian informasi fashion dilihat dari media yang digunakan, alasan memilih media tersebut, frekuensi penggunaan media tersebut dan durasi menggunakan media tersebut. Media yang digunakan dalam pencarian informasi fashion adalah media internet. Saat ini internet sebagai media informasi menjadi media yang 
paling utama dalam melayani kebutuhan informasi penggunanya dengan didukung oleh fasilitas dan teknologi yang semakin canggih. Pemanfaatan internet mengubah pola perilaku masyarakat dalam menentukan informasi yang akan diakses. Melalui internet setiap orang dapat mencari berbagai sumber informasi dengan jumlah yang sangat banyak dan up-to-date.

Novianto (2013) menyatakan perilaku penggunaan internet yang dilakukan oleh responden dilatarbelakangi oleh beberapa motif tertentu, dan motif ini mencakup motif kognitif, pengawasan (surveillance), motif hiburan (entertaiment), motif menghabiskan waktu (passing the time), motif melarikan diri dari kepenatan (escape) dan motif interaksi sosial. Begitupun dalam proses pencarian informasi sebagai dari perilaku penggunaan internet dengan berbagai motif pencarian.

Pada penelitian ini, media yang digunakan dalam pencarian informasi fashion responden diukur dari seberapa banyak responden yang menyatakan bahwa internet adalah media yang yang sering digunakan untuk mencari informasi. Untuk alasan memilih internet sebagai media pencarian informasi diukur dari seberapa banyak responden yang menyatakan bahwa internet mudah diakses dan informasi yang ada internet beragam serta up-to-date. Untuk frekuensi mencari informasi di internet diukur dari seberapa banyak responden yang menyatakan bahwa mencari informasi fashion merupakan rutinitas dan mengakses lebih dari satu kali dalam sehari. Untuk durasi menggunakan internet diukur dari seberapa banyak responden yang menyatakan bahwa mencari informasi fashion lebih dari 30 menit dalam sekali akses.

Berdasarkan uraian di atas dapat disimpilkan bahwa sub variabel X3 yaitu perilaku informasi dalam pencarian informasi fashion berhubungan signifikan dengan variabel $\mathrm{Y}$ yaitu kebutuhan fashion. Hal ini mengindikasikan bahwa media internet yang menyajikan informasi yang up-to-date dan frekuensi penggunaan yang tinggi serta durasi yang lama. Penggunaan internet, alasan memilih internet, frekeunsi penggunaan dan durasi menggunakan berhubungan dengan kebutuhan akan informasi fashion.

\subsection{Uji Hipotesis X dan Y}

Untuk mengetahui apakah terdapat hubungan antara perilaku pencarian informasi perempuan dengan kebutuhan fashion, maka dilakukan analisis statistik dengan menggunakan pearson product moment dengan hipotesis sebagai berikut:

$\mathrm{H}_{0} \quad$ : Perilaku pencarian informasi perempuan berhubungan non signifikan dengan kebutuhan fashion

$\mathrm{H}_{1} \quad$ : Perilaku pencarian informasi perempuan berhubungan signifikan dengan kebutuhan fashion

Berdasarkan hasil pengujian menggunakan uji korelasi pearson product moment di peroleh 0,667. Perhitungan uji korelasi dilakukan menggunakan aplikasi statistik SPSS versi 22 dengan hasil sebagai berikut: 
Tabel 4 Korelasi Antara Perilaku Pencarian Informasi dengan Kebutuhan Fashion

\begin{tabular}{|c|c|c|c|c|}
\hline \multicolumn{5}{|c|}{ Correlations } \\
\hline & & & $\mathrm{X}$ & $\mathrm{Y}$ \\
\hline \multirow[t]{3}{*}{$\mathrm{X}$} & \multirow{3}{*}{$\begin{array}{l}\text { Perilaku Pencarian } \\
\text { Informasi Perempuan }\end{array}$} & Pearson Correlation & 1 & $.667^{* *}$ \\
\hline & & Sig. (2-tailed) & & .000 \\
\hline & & $\mathrm{N}$ & 92 & 92 \\
\hline \multirow[t]{3}{*}{$\mathrm{Y}$} & \multirow[t]{3}{*}{ Kebutuhan Fashion } & Pearson Correlation & $.667^{* *}$ & 1 \\
\hline & & Sig. (2-tailed) & .000 & \\
\hline & & $\mathrm{N}$ & 92 & 92 \\
\hline
\end{tabular}

**. Correlation is significant at the 0.01 level (2-tailed).

Perilaku pencarian informasi perempuan dengan pemenuhan kebutuhan fashion terjadi ketika seseorang memilki motif, dipengaruhi oleh faktor lingkungan dan efek penggunaan media. Menurut Rozinah (2012) perilaku pencarian informasi merupakan tindakan yang dilakukan seseorang untuk memenuhi kebutuhannya. Wilson (2000) menjelaskan perilaku pencarian informasi adalah perilaku mikro, yang ditunjukkan seseorang ketika berinteraksi dengan sistem informasi. Perilaku pencarian informasi bertujuan untuk mencari informasi yang sesuai dengan yang dibutuhkan. Perilaku pencarian informasi timbul karena kebutuhan seseorang untuk menjaga status dengan memiliki lebih banyak pengetahuan tentang suatu topik.

Menurut Belkin (1989) dalam Nicholas (2000) kebutuhan informasi meningkat ketika seseorang menyadari adanya kesenjangan antara pengetahuan dan hasil untuk memecahkan masalah. Untuk mengatasi kesenjangan yang ada, maka seseorang akan mencari informasi yang sesuai dengan kebutuhan yang diinginkan. Pencarian informasi tidak dapat dipisahkan dalam kehidupan sehari - hari. Semua orang mencari informasi untuk memenuhi kebutuhannya. Tidak terkecuali perempuan. Perempuan membutuhkan berbagai jenis informasi salah satunya informasi fashion. Menurut Nugraha (2012) fashion dan perempuan adalah hal yang tidak dapat dipisahkan. Dunia fashion sangat identik dengan perempuan sebagaimana yang dikatakan Wilson dalam Trisnawati (2011) "fashion is righty or wrongly, primarity associated with women".

Perempuan banyak memfungsikan fashion sebagai nilai karena sistem nilai masyarakat yang menuntut perempuan untuk sadar akan kualitas fisiknya. Seorang perempuan sebagai pribadi yang feminin, berusaha untuk selalu menunjukkan indentitas dan jati dirinya dengan menggunakan produk fashion sebagai image dan citra diri mereka. Penghargaan terhadap diri sendiri adalah bagian penting bagi perempuan karena perempuan memperoleh rasa percaya diri ketika menunjukkan eksistensinya di masyarakat. Fashion merupakan objek untuk mendapatkan nilai percaya diri dengan tampil fashionable untuk membuktikan eksistensi dirinya. Oleh karena itu, untuk memenuhi kebutuhan fashion perempuan mencari informasi fashion, sehingga membentuk perilaku pencarian informasi fashion.

Berdasarkan uraian di atas dapat disimpulkan bahwa variabel independen (X) yaitu perilaku pencarian informasi perempuan berhubungan signifikan dengan variabel dependen (Y) yaitu kebutuhan fashion. Hal ini mengindikasikan bahwa perilaku pencarian informasi terjadi ketika seseorang memiliki motif yang dipengaruhi oleh faktor lingkungan dan penggunaan media internet. Perilaku pencarian informasi perempuan berhubungan dengan kebutuhan fashion untuk memenuhi informasi fashion perempuan. 


\section{KESIMPULAN}

Motif individu seperti kebutuhan fisiologis, afektif, dan kognitif dalam pencarian informasi berhubungan dengan kebutuhan fashion. Sebelum mencari informasi, seseorang memiliki motif untuk melakukan pencarian informasi. Motif yang dimiliki ini akan menentukan informasi apa yang akan dicari. Faktor lingkungan seperti lingkungan keluarga, teman, dan media berhubungan dengan kebutuhan fashion. Pencarian informasi dapat dipengaruhi oleh lingkungan sosial yang menuntut untuk mencari informasi secara terus menerus agar kebutuhan akan informasi fashion terpenuhi. Perilaku penggunaan media seperti media yang digunakan, alasan memilih media tersebut, frekuensi serta durasi menggunakan media tersebut berhubungan dengan kebutuhan fashion. Karena ketika kebutuhan meningkat maka pemanfaatan media sebagai sumber informasi merubah pola perilaku dalam menggunakan media sebagai sumber informasi. Perilaku pencarian informasi perempuan berhubungan dengan kebutuhan fashion, karena kebutuhan fashion yang terus berkembang menuntut perempuan untuk terus mencari informasi mengenai fashion. Hal ini membentuk perilaku pencarian yang didasarkan pada motif, faktor lingkungan yang mempengaruhi dan perilaku penggunaan media yang digunakan untuk mendapatkan informasi tersebut.

\section{DAFTAR PUSTAKA}

Batley, Susan. 2007. Information Architecture of Information Professionals. England: Chandos Publishing.

Dewi, Putu Setia Aprilia, Ni Luh Nyoman Kebayantini, and Ikma Citra Ranteallo. 2015. Kebaya Sebagai Media Presentasi Diri Perempuan Bali di Kelurahan Ubud, Gianyar. Jurnal Ilmiah Sosiologi (SOROT). 1 (3): 1-11.

Gumilar, Rizky Agung, Yunus Winoto and Rully Khairul Anwar. 2016. Perilaku Pencarian Informasi di Kalangan Para Pengrajin Golok (Studi Kasus Perilaku Pencarian Informasi Para Pengrajin Golok di Kampung Galonggong Tasikmalaya). Jurnal Kajian Informasi \& Perpustakaan. 4 (1), 1-10. doi:http://dx.doi.org/10.24198/jkip.v4i1.11623.

Heinström, Jannica. 2003. Five Personality Dimensions and Their Influence on Information Behaviour. Information Research. 9 (1).

Hendraningrum, Retno and M. Edy Susilo. 2008. Fashion dan Gaya Hidup: Identitas dan Komunikasi. Jurnal Ilmu Komunikasi. 6 (2): 25-32.

Indah, Cahyo Noer. 2014. Perilaku Penemuan Informasi Mahasiswa Baru. Libri-Net. 3 (1): 41-60.

Kaparang, Olivia. M. 2013. Analisa Gaya Hidup Remaja dalam Mengimitasi Budaya Pop Korea Melalui Televisi. Journal Acta Diurna. 2 (2): 1-25.

Krikelas, James. 1983. Information Seeking Behaviour: Patterns and Concepts. Darxel Library Quartetly. 19 (2): 5-20.

Margaretha, Yolla dan Henky Lisan. 2011. Pengaruh Fashion Clothing Involvement Terhadap Recreational Shopper Identity. Bandung: Universitas Maranatha.

Nicholas, David. 2000. Assessing Information Needs: Tools, Techniques and Concepts For The Internet Age. Second. London: Aslib. 
Novianto, Iik. 2013. Perilaku Penggunaan Internet di Kalangan Mahasiswa (Studi Deskriptif tentang Perilaku Penggunaan Internet di kalangan Mahasiswa Perguruan Tinggi Negeri (Fisip Unair) dengan Perguruan Tinggi Swasta (Fisip UPN) untuk Memenuhi Kebutuhan Informasinya). Libri-Net. 2 (1): 1-40.

Nugraha, Rahmadya Putra. 2012. Fashion Sebagai Pencitraan Diri dan Identitas Budaya. Prosiding Seminar Nasional dalam Rangka Dies Natalis Jurusan Ilmu Komunikasi Fisip Unsoed ke-14. Purwokerto: Universitas Jenderal Soedirman.

Pendit, Putu Laxman. 2003. Penelitian Ilmu Perpustakaan dan Informasi: Sebuah Pengantar Diskusi Epistemologi dan Metodologi. Jakarta: JIP UI.

Prijana, Yunus Winoto, and Andri Yanto. 2016. Metode Penelitian Kuantitatif Ilmu Perpustakaan dan Informasi. Bandung: Unpad Press.

Rozinah, Siti. 2012. Perilaku Pencarian Informasi Mahasiswa dalam Penulisan Skripsi. Depok: Universitas Indonesia.

Rachmawati, Tine Silvana, and Yunus Winoto. 2015. Perilaku Informasi Para Penggali Emas Tradisional (Gurandil) Dalam Melakukan Kegiatan Eksplorasi Dan Pengolahan Tambang Emas." Jurnal Kajian Informasi \& Perpustakaan 3 (1): 33-42. doi:http://dx.doi.org/10.24198/jkip.v3i1.9487.

Sari, Chyntia Kartika, Pawit M. Yusup, and Wina Erwina. 2013. Pola Pencarian Informasi Seniman di Ruang Altrnatif Seni s.14 Bandung. Jurnal Kajian Informasi \& Perpustakaan 1 (2): $117-$ 26. doi:http://dx.doi.org/10.24198/jkip.v1i2.9975.

Trisnawati, Tri. Yulia. 2011. Fashion sebagai Bentuk Ekspresi Diri dalam Komunikasi. The Messenger. 3 (1): 36-47.

Troxell, Mary D and Elaine Stone. 1981. Fashion Merchandising. New York: McGraw-Hill.

Widyastuti, Irmay, Tine Silvana Rachmawati, and Nuning Kurniasih. 2014. Kebutuhan Informasi Gaya Hidup Remaja tentang Fashion di Sekolah Menengah Pertama Negeri 21 Bekasi. Jurnal Kajian Informasi \& Perpustakaan. 2 (2): 81-86. doi:http://dx.doi.org/10.24198/jkip.v2i2.11642.

Wilson, T. D. 1999. Models in Information Behaviour Research. Journal of Documentation. 55 (3): 249-270.

Wilson, T. D. 2000. Human Information Behaviour. Information Science Research. 3 (2): 49-55. http://inform.nu/Articles/Vol3/v3n2p49-56.pdf 
